American Journal of Pharmacology and Toxicology 5 (2): 65-70, 2010

ISSN 1557-4962

C 2010 Science Publications

\title{
Effect of Garcinia Atroviridis on Oxidative Stress and Atherosclerotic Changes in Experimental Guinea Pigs
}

\author{
${ }^{1}$ Adel.A. Amran, ${ }^{1}$ Zaiton Zakaria, ${ }^{2}$ Faizah Othman and ${ }^{3}$ Paden Morat \\ ${ }^{1}$ Department of Physiology, \\ ${ }^{2}$ Department of Anatomy,
}

Faculty of Medicine, University Kebangsaan Malaysia, 50300 Kuala Lumpur, Malaysia

${ }^{3}$ Department of Biomedical, Faculty of Allied Science, University Kebangsaan Malaysia, Jalan Raja Muda Abd. Aziz, 50300 Kuala Lumpur, Malaysia

\begin{abstract}
Problem statement: Oxidative stress plays a major role in hypercholesterolemia induced atherosclerosis. Garcinia atroviridis has been shown to exhibit antioxidant properties. Approach: The present study aimed to investigate the effect of Garcinia atroviridis on the oxidative stress in guinea pigs fed with high cholesterol diet. Twenty-four male Guinea pigs were divided into four groups. Group I served as control while group II, III, IV were fed with $1 \%$ cholesterol diet in rabbit chow pellet, fed with both $1 \%$ cholesterol diet plus $50 \mathrm{mg} \mathrm{body}^{-1}$ weight of Garcinia atroviridis, fed with Garcinia atroviridis only $\left(50 \mathrm{mg} \mathrm{mL}^{-1}\right.$ water body ${ }^{-1}$ weight $)$, respectively. All animals were sacrificed by cardiac puncture and the blood was collected for the determination of malonaldialdehyde and DNA damage using comet assay and histology of the aorta was performed. Results: The results showed a significant increase in the percentage of DNA damage in the tail and in the tail moment (comet assay) in the group II compared to the group I. Group III showed pattern of reduction in the percentage of DNA damage by $42 \%$ and tail moment by $50 \%$ compared to the group II. There were no significant changes in the MDA levels in serum, liver and heart in all groups. Histological studies in group III showed a tendency in the reduction of the fat deposition in the aorta and number of foam cells compared to the group II. Conclusion: The supplementation with Garcinia atroviridis reduced the DNA damage and deposition of lipids in the wall of the aorta in hypercholesteromic guinea pigs.
\end{abstract}

Key words: Oxidative stress, Garcinia atroviridis, extract, atherosclerosis, aorta, histology

\section{INTRODUCTION}

Oxidative Stress (OS) is a term used to describe the steady state level of oxidative damage in cells, tissues, or organs caused by the Reactive Oxygen Species (ROS). It is imposed on cells as a result of an increase in oxidant generation, a decrease in antioxidant protection and a failure to repair oxidative damage. Oxidative Stress (OS) occurs when antioxidant defense mechanisms are overwhelmed by free radicals either due to increased free radical formation or decreased antioxidant capacity (Sohal and Weindruch, 1996).

There is an increase in evidence which shows that atherosclerosis is associated with damage of the DNA of both the circulating cells as well as the cells of the vessel wall (Andreassi, 2006). Reactive oxygen species are the most likely agents inducing DNA damage in atherosclerosis. DNA damage produces a variety of responses, including cell senescence; apoptosis and DNA repair (Kapoor and Prasad, 1994).
Garcinia atroviridis is a medium sized fruit tree which belongs to the family Gutiferae. In Malaysia it is popularly known as 'asam gelugur' or 'asam keping'. The plant contains citric, tartaric and ascorbic acid which have antioxidant activities. However, the most important bioactive compound is Hydroxyl Citric Acid (HCA) (Seon-Min et al., 2001). Garcinia atroviridis extract exhibit strong antioxidant, antimicrobial, antitumour and anti-inflammatory activities (Mackeen et al., 2000). The present study aimed to investigate the effects of Garcinia atroviridis on oxidative stress and atherosclerosis in guinea pigs administered with high cholesterol diet.

\section{MATERIALS AND METHODS}

Garcinia atroviridis extract preparation: G. atroviridis fruits were purchased from a local supplier and were identified by a pharmacognosy expert in the

Corresponding Author: Zaiton Zakaria, Department of Physiology, Faculty of Medicine, University Kebangsaan Malaysia, 50300 Kuala Lumpur, Malaysia Tel: 603-40405577/603-40405223 Fax: 603-26939687 
Department of Pharmacy, Faculty of Allied Science. G. atroviridis fruits were prepared by air-drying and cutting them into small pieces $(600 \mathrm{~g})$, which were successively extracted with methanol (99.8\%) using a Soxhlet extractor. The resultant solution was filtered and dried using a rotatory evaporator in a water bath at a temperature not exceeding $50^{\circ} \mathrm{C}$.

Animal studies: Twenty-four male Dunkin Hartley guinea pigs weighing between $700-1000 \mathrm{~g}$ were used. The cholesterol and lipoprotein metabolism in guinea pigs have remarkable similarities to that of human metabolism (Fernandez, 2001). We followed the previous protocol where guinea pigs were used as a model of atherosclerosis (Toshi et al., 1991).

Male Dunkin-Hartley guinea pigs $(n=24)$ were divided into four groups with six animals in each group (Table 1). Group I (control) consisted of animals fed with commercial rabbit chow. Group II were fed with $1 \%$ cholesterol diet in rabbit chow pellet only, to induce atherosclerosis (in $100 \mathrm{~g}$ of crushed rabbit chow pellet, $1 \mathrm{~g}$ of cholesterol powder was added and mixed with $50 \mathrm{~mL}$ of sterile distilled water and the mixture was made into pellet form and dried in an oven under $50^{\circ} \mathrm{C}$ overnight). Group III was fed with both $1 \%$ cholesterol diet plus $50 \mathrm{mg} /$ body weight Garcinia atroviridis, while Group IV was fed with Garcinia atroviridis (50 mg mL ${ }^{-1}$ water/body weight). All the treatment were given daily for 60 days. The diets were obtained from The Laboratory Animal Resource Unit Faculty of Medicine, University Kebangsaan Malaysia (UKM). The animals were housed in cages maintained under standard conditions (temperature $24^{\circ} \mathrm{C}$, light/darkness cycles of $12 \mathrm{~h}$ ) with free access to food and water, in addition to a twice weekly, vegetable diet of mustard leaves cabbage and carrot. Garcinia atroviridis was forced fed with a gastric lavage. The experiment was approved by the Animal Ethical Committee of University Kebangsaan Malaysia (UKM) and the animal care was given according to approved standards for laboratory animal care.

The animals were kept on their respective diets for 2 months. After two months of diet, the animals were fasted overnight in preparation for serum and tissue collection. In the morning, the animals were weighed, anesthetized by chloroform and the thoracic abdominal cavity was opened. Blood was collected by cardiac puncture and serum was separated by centrifugation at $3000 \mathrm{rpm}$ for $5 \mathrm{~min}$ and serum was collected and kept in refrigerator at $-76^{\circ} \mathrm{C}$ until needed. The heart together with the abdominal aorta $(2-3 \mathrm{~cm}$ length) was excised from each animal. The aorta was cut at the origin and removed from the heart. A $2 \mathrm{~mm}$ section of the aorta of each animal was soaked in a $10 \%(\mathrm{v} / \mathrm{v})$ formal saline solution for $\mathrm{H}$ and $\mathrm{E}$ staining. The liver and heart were soaked in de-ionized water and homogenized for biochemical analysis.

Determination of malonaldialdehyde in serum, liver and heart: Malonaldialdehyde levels in the supernatant and serum were measured as Thiobarbituric Acid Reactive substances (TBARs) according to a previously described method (Melli et al., 2006; Ohkawa et al., 1979). TBARs were extracted in a mixture of butanol:pyridine (15:1) which was separated by centrifugation. In brief, $0.5 \mathrm{ml}$ each of sample was mixed with $2.5 \mathrm{~mL}$ of $20 \%$ Trichloroacetic Acid (TCA) (Sigma, Germany), vortexed and then left for $15 \mathrm{~min}$. Then $1.5 \mathrm{~mL}$ of $0.2 \mathrm{~g} \mathrm{dL}^{-1}$ Thiobarbituric Acid (TBA) (Sigma, Germany) reagent was added and vortexed again. The mixture was heated in a boiling water bath for $30 \mathrm{~min}$. After cooling in cold water, the resulting chromogen was extracted with $4 \mathrm{ml}$ of n-butyl alcohol and then vigorously vortexed for $4 \mathrm{~min}$. The organic phase was separated by centrifugation at $3000 \mathrm{rpm}$ for $10 \mathrm{~min}$ and absorbance was recorded at wavelength of $532 \mathrm{~nm}$. A Malondialdehyde (MDA) solution made freshly by the hydrolysis of $1,1,3,3$,Tetramethoxypropane (TMP) (Sigma, Germany) was used as the standard. MDA was dissolved in $0.05 \mathrm{M}$ sulphuric acid to prepare $10 \mathrm{mM}$ stock solution. By diluting the stock solution, different concentrations (1-5 nmol $\left.\mathrm{mL}^{-1}\right)$ of MDA were obtained in order to prepare a standard curve. Protein content of the sample was measured by Biuret method (Gornall et al., 1949). The results are expressed as the nmol MDA mg ${ }^{-1}$ protein.

Comet assay: The assay was performed immediately after blood withdrawal; in accordance with previously published methods (Lemay and Wood, 1999; Sun et al., 2005) using the comet assay kit (Trevigen, Inc., Gaithersburg, MD) with some modification. The whole blood was taken and the blood cells were combined at a ratio of 1:10 with molten, low melting point agarose kept at $37^{\circ} \mathrm{C} .75 \mu \mathrm{L}$ of the mixture were immediately pipetted and evenly spread onto Comet slides that are specially coated with high melting point agarose.

Table 1: Experimental diet group each group contain six animals

\begin{tabular}{ll}
\hline Group & Diet/treatment \\
\hline Group I & Control (rabbit chow diet) \\
Group II & $\begin{array}{l}\text { Cholesterol diet ( } 1 \% \text { cholesterol in rabbit chow diet) } \\
\text { Group III }\end{array}$ \\
& $\begin{array}{l}\text { Cholesterol diet }+ \text { Garcinia atroviridis }(1 \% \text { cholesterol diet } \\
\text { supplemented with Garcinia atroviridis } 50 \mathrm{mg}_{\text {body }}^{-1} \text { weight) }\end{array}$ \\
Group IV & $\begin{array}{l}\text { Garcinia atroviridis (rabbit chow diet supplement with } \\
\text { Garcinia atroviridis } 50 \mathrm{mg} \mathrm{body}^{-1} \text { weight) }\end{array}$
\end{tabular}


The slides were kept at $4^{\circ} \mathrm{C}$ for $30 \mathrm{~min}$ to allow the agarose to solidify and then immersed in prechilled lysis buffer solution for $60 \mathrm{~min}$ at $4^{\circ} \mathrm{C}$. Subsequently, the slides were immersed into freshly prepared alkali solution (300 mM NaCl and $1 \mathrm{mM}$ EDTA) for $20 \mathrm{~min}$. The slides were then transferred to an electrophoresis chamber and fresh alkali solution was poured to sufficiently cover the slides. Electrophoresis was done at $300 \mathrm{~mA}, 27 \mathrm{~V}$ (constant voltage) for $20 \mathrm{~min}$. Subsequently, the slides were rinsed in Tris-EDTA (TE) solution [10 mM Tris (pH 7.5) and $1 \mathrm{mM}$ EDTA] and then fixed in $100 \%$ ice-cold ethanol for $5 \mathrm{~min}$. The samples were air-dried at room temperature and the cells were viewed by staining with $50 \mu \mathrm{L}$ of ethedium bromide. The blood cells were viewed under a fluorescence microscope (excitation/emission at 510/515 nm; Zeiss Corporation, USA) with camera axiocam MRC Zeiss, USA. The results were interpreted as quantitative analysis of DNA damage by counting one hundred comets on each slide and were analyzed using epifluorescence microscope equipped with 515 barrier filter and 560 emission filter with Computerized image analysis with software comet score (USA). The program was designed to differentiate comet head from tail and to measure a variety of parameters including tail length, \%DNA in tail, comet area, head diameter, tail area and tail moment.

Histological analysis of aorta: The aorta was embedded in paraffin as the final process of making tissue blocks, which were then trimmed and sectioned with a microtome (Leica, Wetzlar, Germany) at room temperature to obtain $4 \mu \mathrm{m}$ sections. The ribbons of sections floated in a $50^{\circ} \mathrm{C}$ water bath (leica bath H1210), were "fished" and mounted onto the poly-Llysine-treated glass slides. The sections were then deparaffinised on a $60^{\circ} \mathrm{C}$ hot plate. This was followed by a hydration process, which included immersion in xylene for $2 \mathrm{~min}$ and a series of steps of decreasing ethanol concentrations beginning with absolute ethanol ( $2 \mathrm{~min}$ ), 95\% ethanol (2 $\mathrm{min}$ ) and $80 \%$ ethanol (2 min). The slides were then dipped in $3 \%$ hydrogen peroxide for $15 \mathrm{~min}$ and then examined under a light microscope for observing the histology of the aorta. The sections were examined blindly using scoring system (Kannel et al., 1979). The scores were given as 0 (if no lesion is detected), 1 (about 33\% of lesion detected), 2 (about $33-66 \%$ of lesion detected) and 3(above $66 \%$ of lesion detected).

The parameter values were all expressed as the mean \pm SD. Normal distribution of all variables was examined by Kolmogrov-Smirnov test. Significant differences among the groups were determined by oneway ANOVA using SPSS 12.0 software package program. The results were considered significant if the value is $\mathrm{p}<0.05$.

\section{RESULTS}

Serum and tissue MDA: The MDA content of the serum and tissue at 60 days from the four experimental groups were summarized in (Fig. 1). There were no significant differences between MDA in serum, liver and heart. There were no correlation between MDA in serum, liver or heart in the all groups.

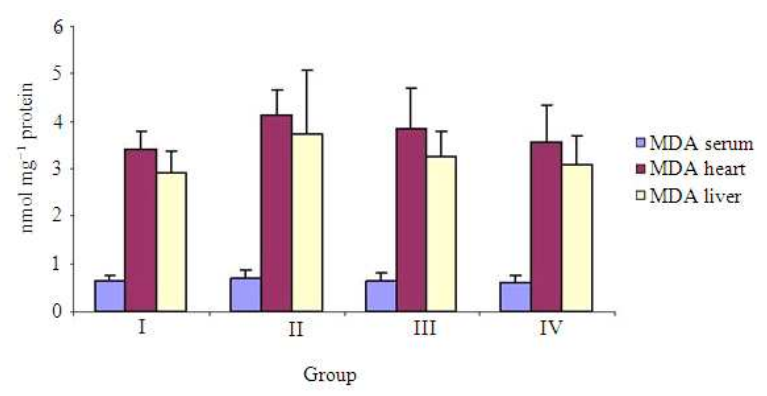

Fig. 1: MDA serum/heart/liver in different groups all result by mean $\pm \mathrm{SD}$
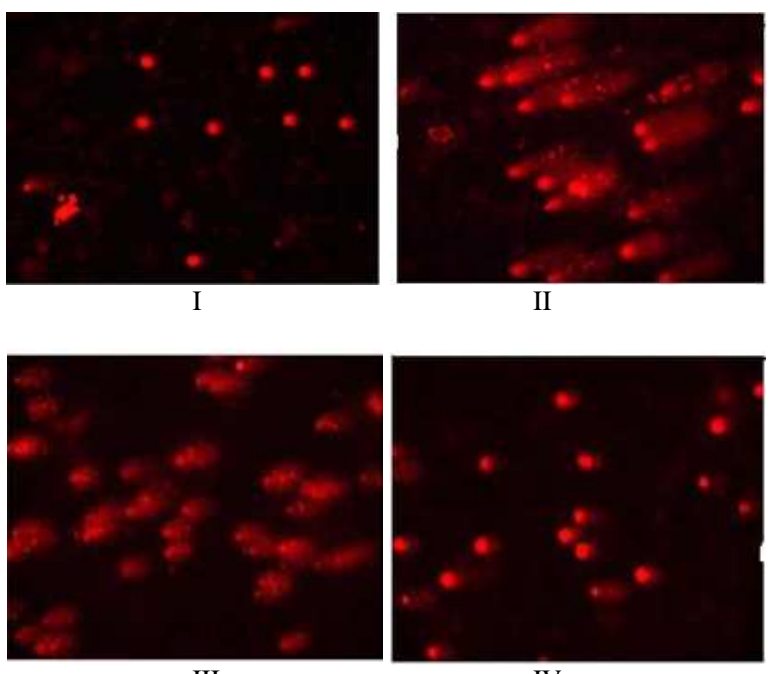

III

IV

Fig. 2: Ethidium bromide-stained in Comet assay test in all group. Long tail with clear headImage of damaged cell. Comet image representative of damaged cell. After electrophoresis the stained DNA results in a Comet-like image 


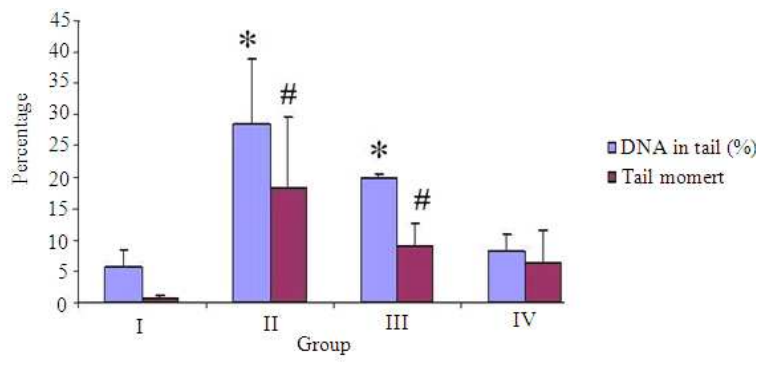

Fig. 3: DNA in tail (\%) and Tail moment (comet assay) in the different groups. $\mathrm{p}<0.05$ compared to I and IV; $\mathrm{p}<0.01$ compared to I and IV

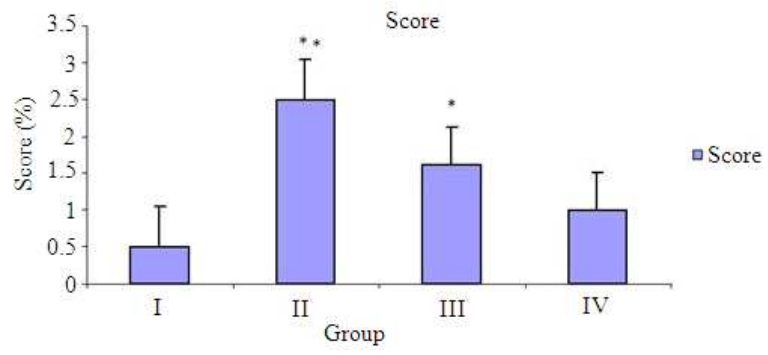

Fig. 4: Scoring for aorta histology in nt groups the values appears as mean \pm SD. **: $\mathrm{p}<0.01$ compared to I and IV; *: p < 0.05 compared to I and IV

Comet assay: The majority of cells examined by the alkaline comet assay had a normal morphology in group I (no tail or DNA damage) (Fig. 2). However, the DNA damage in tail was significantly higher in the group II compared with the group I. Each cell had the appearance of a comet, with a brightly fluorescent head and a tail with an intensity that was related to the amount of damage sustained by the cell. In the group III there was a trend of DNA damage reduction in tail comet which was insignificant compared to group II (Fig. 3).

Histological analysis: Although the group II and III both showed significant increase in the percentage score of atheromatous plaque compared to group I, but the $\mathrm{G}+\mathrm{C}$ was showed a tendency to decrease the score by $56 \%$ compare to group II (Fig. 4 ).

\section{DISCUSSION}

Hypercholesterolemia has been documented as an important risk factor of atherosclerosis (Chen et al., 1999). Cardiac morbidity and mortality are directly related to serum cholesterol level. The consumption of a cholesterol-enriched diet increases the degree of lipid peroxidation, which is also one of the early stages in the progression of atherosclerosis (Chen et al., 1999). It has been reported that some antioxidants can prevent atherosclerosis by protecting LDL from oxidation and are also associated with an anticholesterolemic effect (Freyschuss et al., 2001; Ghasi et al., 2000). Many plant extracts have been shown to exhibit hypocholesterolemic activity in guinea pigs and rabbits (Vasu et al., 2005; Prasad, 1999).

In the present study, levels of serum and tissue MDA were elevated in guinea pig on high cholesterol diet and Garcinia atroviridis when administered only without cholesterol, reduced the serum and aortic MDA but it was insignificant. Increase in the level of MDA in tissue and serum in high cholesterol-fed have been reported earlier (Henrikssen et al., 1987; Prasad and Lee, 2003; Nor Fadilah et al., 2005). In the present study group IV reduced the serum, liver and heart tissue MDA by 10,14 and $8 \%$ respectively as compared to the group II but the reduction was insignificant. Garcinia atroviridis contain hydroxycitric acid which has antioxidant activities which could reduce MDA level. In the present study, the concentration and duration of Garcinia atroviridis probably was not enough to reduce the MDA level, significantly.

This study showed that group III reduced DNA damage by 42 and $50 \%$ decrease in tail moment compared to group II but both were insignificant. Our results are in accordance with another study which reported that Garcinia atroviridis reduced the percentage of cells with DNA damage over a period of time (Andreassi and Nicoletta, 2003). Previous studies demonstrated that the DNA damage was significantly associated with the development and the progression of atherosclerosis (Amran et al., 2009; Recep et al., 2005). It was also demonstrated that DNA damage increased in patients with Coronary Artery Disease (CAD) (Singh et al., 1988).

Histological study demonstrated that ethanol extract of Garcinia atroviridis had a tendency to reduce atherosclerotic lesions in the aorta. The descriptive results of the histological studies have been reported earlier (Wim et al., 2002). Several epidemiological studies showed that increased dietary intake of natural antioxidants correlates to reduced coronary heart disease. Food rich in antioxidants play an essential role in the prevention of cardiovascular diseases, cancer and neurodegenerative disease (Gerber et al., 2002; Di and Esposito, 2003). Antioxidants are known to alleviate oxidative stress which is generally perceived as one of the major causes for the accumulation of mutations in the genome.

\section{CONCLUSION}

In conclusion, supplementation of Garcinia. atroviridis to hypercholesterolemic guinea pigs has a 
tendency to reduce the progression of atherosclerosis by reducing the oxidative stress. Hence, in the future Garcinia atroviridis may be used as a supplement in the treatment of atherosclerosis.

\section{ACKNOWLEDGEMENT}

This study was supported by the research grant from Ministry of Science, Technology and Innovation and approved by the University Animal Ethical Committee (FISIO/2006/ZAITON/19-APRIL/166DECEMBER-2006). The authors wished to record their appreciation for the assistance and facilities provided by University Kebangsaan Malaysia for this study. The authors also thanked Dr. Srijit Das from Department of Anatomy, Mr Michael from the Animal House UKM, Mrs. Zanaryah Asmawi, Dr. Hesham Al-mekhlafi and Dr. Riyadh Saif for their various contribution to come out with this article.

\section{REFERENCES}

Amran, A.A., Z. Zaiton, O. Faizah and P. Morat, 2009. Effects of Garcinia atroviridis on serum profiles and atherosclerotic lesions in the aorta of guinea pigs fed a high cholesterol diet. Singapore Med. J., 50: 295-299.

Andreassi, G., 2006. Oxidative stress, DNA damage and vascular endothelial function. Biomed. Pharmacother., 60: 482-482.

Andreassi, M.G and B. Nicoletta, 2003. DNA damage as a new emerging risk factor in atherosclerosis. Trends Cardiovas. Med., 13: 270-275.

Chen, M.F., H.C. Hsu, C.S. Liau and Y.T. Lee, 1999. The role of Vitamin $\mathrm{E}$ on the antiatherosclerotic effect of fish oil in diet-induced hypercholesterolemic rabbits. Prostagland. Lipid Mediators, 57: 99-101.

Di, M.V. and E. Esposito, 2003. Biochemical and therapeutic effects of antioxidants in the treatment of Alzheimer's disease, Parkinson's disease and amyotrophic lateral sclerosis. Curr. Drug Targets: CNS Neurol. Disord., 2: 95-97.

Fernandez, M.L., 2001. Guinea pigs as models for cholesterol and lipoprotein metabolism. J. Nutr., 131: 10-20.

Freyschuss, A., A. Al-Schurbaji, I. Bjorkhem, A. Babiker and U. Diczfalusy et al., 2001. On the antiatherogenic effect of the antioxidant BHT in cholesterol-fed rabbits: Inverse relation between serum triglycerides and atheromatous lesions. Biochim. Biophys. Acta, 1534: 129-138.
Gerber, M., C. Boutron, S. Hereberg, E. Riboli and A. Scalbert et al., 2002. Food and cancer: State of the art about the protective effect of fruits and vegetables. Bull. Canc., 89: 293-302.

Ghasi, S., E. Nwobodo and J.O. Ofili, 2000. Hypocholesterolemic effects of crude extract of leaf of Moringa oleifera Lam in high-fat died fed wistar rats. J. Ethnopharmacol., 69: 21-25.

Gornall, A.G., C.J. Bardawill and M.M. David, 1949. Determination of serum proteins by means of biuret reaction. J. Biol. Chem., 177: 751-766.

Henrikssen, P., M. Stamberger and U. Diczfalusy, 1987. Increased aortic thromboxane production in experimental atherosclerosis. Prostagland. Leukot Med., 29: 71-77.

Kannel, W.B., W.P. Castelli and T. Gordon, 1979. Cholesterol in the prediction of atherosclerotic disease. Ann. Inter. Med., 90: 85-91.

Kapoor, R. and K. Prasad, 1994. Role of oxyradicals in cardiovascular depression and cellular injury in hemorrhagic shock and reinfusion: Effect of SOD and catalase. Circ Shock, 43: 79-94.

Lemay, M. and K.A. Wood, 1999. Detection of DNA damage and identification of UV-induced photoproducts using the Comet Assay Kit. BioTechniques, 27: 846-851.

Mackeen, M.M., A.M. Ali, N.H. Lajis, K. Kawazu and Z. Hassan et al., 2000. Antimicrobial, antioxidant, antitumour-promoting and cytotoxic activities of different plant part extracts of Garcinia atroviridis Griff. exT. Anders. J. Ethanopharmacol., 3: 395-402.

Melli, M., M. John and B. Martin, 2006. DNA damage and repair in atherosclerosis. Cardiovas. Res., 71: 259-268.

Nor Fadilah, R., R. Ariffi, M. Engku Norbaya and H. Asmah, 2005. Toxicological evaluation of Solanum torvum and Garcinia atroviridis fruit extracts. Malaysian J. Biochem. Mol. Biol., 11: 88-88.

Ohkawa, H., N. Ohishi and K. Yagi, 1979. Assay for lipid peroxides in animal tissue by thiobarbituric acid reaction. Anal. Biochem., 95: 351-358.

Prasad, K., 1999. Reduction of serum cholesterol and hypercholesterolemic atherosclerosis in rabbits by secoisolariciresinol diglucoside isolated from flaxseed. Circulation, 99: 1355-13362.

Prasad, K. and P. Lee, 2003. Suppression of oxidative stress as a mechanism of reduction of hypercholesterolemic atherosclerosis by aspirin. J. Cardiovas. Pharmacol. Ther., 8: 61-69.

Recep, D., Y. Remzi and K. Abdurrahim, 2005. Relationship between DNA damage, total antioxidant capacity and coronary artery disease. Mutat. Res., 570: 197-203. 
Seon-Min, J., B. Song-Hae, J. Moon-Kyoo, M.K. Lee and K.T. Nam et al., 2001. Antioxidative activity of naringin and lovastatin in high cholesterol-fed rabbits. Life Sci., 69: 2855-2866.

Singh, N.P., T. Mc Coy, R. Tice and L. Schneider, 1988. A simple technique for quantization of low levels of DNA damage in individual cells. Exp. Cell Res., 175: 184-191.

Sohal, R.S. and R. Weindruch, 1996. Oxidative stress, caloric restriction and aging. Science, 273: 59-63.

Sun, J.H., D. Min, N. Kichang, W. Mark and A. Dong, 2005. Effect of dietary fats on blood cholesterol and lipid and the development of atherosclerosis in rabbits. Nutr. Res., 25: 925-935.
Toshi, M., O. Minoru and H. Mitsuru, 1991. Does chylomicronemia cause atherosclerosis? Tohoku J. Exp. Med., 163: 129-134.

Vasu, V.T., H. Modi, V. Thaikoottathil and S. Gupta, 2005. Hypolipidaemic and antioxidant effect of Enicostemma littorale Blume aqueous extract in cholesterol fed rats. J. Ethnopharmacol., 101: 277-282.

Wim, M., K. Michiel, D. Guido, H. Arnold and K. Mark, 2002. Elevated levels of oxidative DNA damage and DNA repair enzymes in human atherosclerotic plaques. Circulation, 106: 927-932. 